\title{
The Synthesis of some Polyether Bridged Diphosphines and their Reaction with $\mathrm{Rh}(\mathrm{COD}) \mathrm{acac}$
}

\author{
KLAAS TIMMER and D. HARRY M. W. THEWISSEN* \\ Institute of Applied Chemistry TNO, P.O. Box 5009, 3502 JA Utrecht, The Netherlands
}

Received August 7, 1984

\section{Abstract}

The polyether bridged diphosphines,<smiles>[R20]c1ccccc1OCCOCCOc1ccccc1OCCO</smiles>

$(\mathrm{n}=1,2)$ have been prepared in $60-70 \%$ yield by reduction of the corresponding diphosphinedioxides with $\mathrm{Si}_{2} \mathrm{Cl}_{6}$ or $(\mathrm{i}-\mathrm{Bu})_{2} \mathrm{AlH}$. These diphosphinedioxides have been prepared in $75-90 \%$ yield by reaction of two equivalents of the appropriate<smiles>[R6]O[PH2+]c1ccccc1O[N+]=[N-]</smiles>

with one equivalent of di- and triethylene glycol ditosylate.

In general, reaction between the diphosphines, $\mathrm{Rh}$ (COD)acac and $\mathrm{HClO}_{4}$ gives a mixture of species, cis- $[\mathrm{Rh}(\mathrm{COD})(\widehat{\mathrm{PP}})]\left[\mathrm{ClO}_{4}\right]$ being the main complex. This complex reacts with $\mathrm{CO}$ to $\eta^{3}$-trans$\left[\mathrm{Rh}(\mathrm{CO})\left(\mathrm{POOP}^{-}\right)\right]\left[\mathrm{ClO}_{4}\right]$.

\section{Introduction}

Bidentate neutral organophosphorus compounds with a (poly)ether chain interlinking two phosphorus nuclei are expected to possess special ligating properties and are, as a matter of fact, of potential interest in view of various important applications.

In a previous paper Alberts et al. have shown that diphosphinedioxide (poly)ethers can act as a guest for host molecules like amino acid ester salts, in which the host is encapsulated in the cavity of the macrocyclic receptor [1]. Diphosphinedioxides are also likely to have the ability to interact with metal ions. This is of importance with respect to extraction of heavy metals, in particular transplutonium elements. For this purpose bidentate organo-

\footnotetext{
*Author to whom correspondence should be addressed.
}

phosphorus derivatives have proven better extractants than their monodentate analogues, probably due to the chelate effect [2].

Recently, we have also reported on the synthesis of some $R h(C O D)$ diphosphino-(poly)ether complexes [3]. By cis-chelation of the diphosphino ligand a macrocycle containing ether functions may be realised in the vicinity of the metal centre. The possibility of storing small less reactive molecules in the polyether cavities of these complexes makes them highly interesting in view of chemical and catalytic reactions.

In this paper we describe the synthesis and spectroscopic characterisation of three $\alpha, \omega$-diphosphinedioxide (poly)ether molecules and the corresponding diphosphino analogues, as well as the interaction of the latter derivatives with $\mathrm{Rh}(\mathrm{I})$.

\section{Experimental}

Unless noted otherwise, reactions were carried out under nitrogen at room temperature, in analytical grade solvents, which were dried and distilled before use. $\mathrm{Si}_{2} \mathrm{Cl}_{6}$ (Aldrich), (i-Bu) $)_{2} \mathrm{AlH}$ (Schering A.G.) and 55\% NaH in mineral oil (Fluka) were commercially obtained. Diethylene glycol ditosylate (m.p. $87-88{ }^{\circ} \mathrm{C}$ ) was prepared in $86 \%$ yield from diethylene glycol (Fluka) and p-toluene sulfonylchloride (Merck) in pyridine; likewise triethyleneglycol ditosylate (m.p. $75-76{ }^{\circ} \mathrm{C}$ ) was obtained in $89 \%$ yield from triethylene glycol (Fluka). Rh(COD)acac was synthesised according to a literature procedure [4].

Microanalyses were performed at the elementanalytical department of the Institute of Applied Chemistry TNO, Zeist. Routine infrared spectra were measured on a Perkin-Elmer 577 spectrophotometer $\left(4000-200 \mathrm{~cm}^{-1}\right)$ in $\mathrm{KBr}$ discs. NMR spectra were recorded on a Bruker WH 90 spectrometer in $\mathrm{CDCl}_{3}$ as the solvent. ${ }^{1} \mathrm{H}-\mathrm{NMR}$ chemical shifts are given in units of $\delta$, relative to TMS ( $\mathrm{s}=$ singlet, $\mathrm{d}=$ doublet, $\mathrm{t}=$ triplet, $\mathrm{m}=$ multiplet ). ${ }^{13} \mathrm{C}$-NMR shifts were recorded at $22.63 \mathrm{MHz}$, relative 
to TMS. ${ }^{31} \mathrm{P}-\mathrm{NMR}$ shifts were measured at 36.44 $\mathrm{MHz}$ relative to an external $85 \% \mathrm{H}_{3} \mathrm{PO}_{4}$ standard. Couplings are given in $\mathrm{Hz}$.

\section{1,5-Dil/2-diphenylphosphineoxido/phenoxy]-3-oxa- pentane 1}

$5.88 \mathrm{~g}(20 \mathrm{mmol})$ of (o-hydroxyphenyl)diphenylphosphineoxide [1] was added to a solution of 0.46 $\mathrm{g}(20 \mathrm{mmol})$ of sodium ethoxide in $30 \mathrm{ml}$ of ethanol. After refluxing for one hour and cooling to room temperature $3.73 \mathrm{~g}(9 \mathrm{mmol})$ of diethylene glycol ditosylate was added, together with $10 \mathrm{ml}$ of ethanol. The mixture was refluxed for five hours. After evaporation of the solvent $50 \mathrm{ml}$ of $\mathrm{CH}_{2} \mathrm{Cl}_{2}$ and $50 \mathrm{ml}$ of $0.5 \mathrm{n} \mathrm{NaOH}$ in $\mathrm{H}_{2} \mathrm{O}$ were added to the residue. Upon shaking, the water layer was removed and the organic layer was washed with $50 \mathrm{ml}$ of $0.5 \mathrm{n} \mathrm{NaOH}$ in $\mathrm{H}_{2} \mathrm{O}$ and $50 \mathrm{ml}$ of $\mathrm{H}_{2} \mathrm{O}$ respectively. The organic layer was dried on $\mathrm{MgSO}_{4}$. After filtration and evaporation of the $\mathrm{CH}_{2} \mathrm{Cl}_{2}$, the product was recrystallised from $\mathrm{CH}_{2} \mathrm{Cl}_{2} /$ hexane. Initially, the product was obtained as the clathrate with $\mathrm{CH}_{2} \mathrm{Cl}_{2}$, m.p. $123-124{ }^{\circ} \mathrm{C}$. The solvent molecule is lost upon heating at $130{ }^{\circ} \mathrm{C}$ in vacuo for three hours. Yield 90\%. Anal. Calcd. for formula $\mathrm{C}_{40^{-}}$ $\mathrm{H}_{36} \mathrm{O}_{5} \mathrm{P}_{2}: \mathrm{C}, 72.95, \mathrm{H}, 5.47, \mathrm{P}, 9.42, \mathrm{O}, 12.16$, Found: C, 72.44, H, 5.32, P, 9.49, O, 12.43 .

\section{1,8-Di[/2-diphenylphosphineoxido)phenoxy]-3,6- dioxaoctane 2}

$4.26 \mathrm{~g}(14.5 \mathrm{mmol})$ of (o-hydroxyphenyl)diphenylphosphineoxide [1] was suspended in $35 \mathrm{ml}$ of DMF. Then $0.7 \mathrm{~g}$ of $55 \% \mathrm{NaH}(16 \mathrm{mmol})$ in mineral oil was added in portions. After vigorous stirring at $80{ }^{\circ} \mathrm{C}$ for one hour and cooling to room temperature $2.98 \mathrm{~g}(6.5 \mathrm{mmol})$ of triethylene glycol ditosylate was added, together with $10 \mathrm{ml}$ of DMF. Stirring at $80{ }^{\circ} \mathrm{C}$ was continued for four hours. The solvent was evaporated and the work-up was similar to the procedure described above. The product was now purified by washing with boiling ether for four hours. Yield: $89 \%$. Anal. Calcd. for formula $\mathrm{C}_{42} \mathrm{H}_{40} \mathrm{O}_{6} \mathrm{P}_{2}$ : C, 71.80, $\mathrm{H}, 5.70, \mathrm{P}, 8.83$, $\mathrm{O}, 13.68$, Found: C, 71.41, H, 5.54, P, 8.89, O, 13.91 .

\section{1,5-Di/(2-methyl phenyl phosphineoxido/phenoxy]- 3-oxapentane 3}

Methyl ( $o$ - methoxyphenyl)phenylphosphineoxide was prepared in $94 \%$ yield from reaction of $o$-methoxyphenylmagnesium bromide with menthyl methylphenylphosphate $(+,-)$. Subsequent demethylation with $\mathrm{BBr}_{3}$ gave methyl (o-hydroxyphenyl)phenyl phosphineoxide, m.p. $165-167^{\circ} \mathrm{C}$ in $74 \%$ yield.

$9.5 \mathrm{~g}(41 \mathrm{mmol})$ of methyl(o-hydroxyphenyl)phenylphosphineoxide was dissolved in $70 \mathrm{ml}$ of DMF. $1.97 \mathrm{~g}(45 \mathrm{mmol})$ of $55 \% \mathrm{NaH}$ in mineral oil was then added in portions. After vigorous stirring at $80{ }^{\circ} \mathrm{C}$ for $0.5 \mathrm{~h}$ and cooling to room temperature $7.68 \mathrm{~g}$ (18.55 mmol) of diethylene glycol ditosylate was added, with $5 \mathrm{ml}$ of DMF. Stirring at $80{ }^{\circ} \mathrm{C}$ was continued for five hours. The solvent was removed by evaporation and the work-up was similar to the procedure described for 1 . The product was purified by washing with ether at room temperature. Yield 79\%. Anal. Calcd. for formula $\mathrm{C}_{30} \mathrm{H}_{32} \mathrm{O}_{5} \mathrm{P}_{2}$ : C, 67.41, H, 5.99, P, 11.61, O, 14.98, Found: C, $66.96, \mathrm{H}, 6.15, \mathrm{P}, 11.32, \mathrm{O}, 15.49$.

\section{Preparation of the Phosphines (4-6)}

Two methods were employed to reduce the phosphineoxides to the corresponding phosphines.

a $15 \mathrm{mmol}$ of the appropriate phosphineoxide was suspended in $40 \mathrm{ml}$ of acetonitrile. $8.07 \mathrm{~g} \mathrm{(30}$ $\mathrm{mmol}$ ) of hexachlorodisilane was added dropwise under vigorous stirring. Stirring was continued for $0.5 \mathrm{~h}$ at room temperature, followed by three hours at reflux temperature. Upon cooling to $0{ }^{\circ} \mathrm{C}, 50$ $\mathrm{ml}$ of $4 \mathrm{n} \mathrm{NaOH}$ in $\mathrm{H}_{2} \mathrm{O}$ was added dropwise. After addition of $50 \mathrm{ml}$ of $\mathrm{CH}_{2} \mathrm{Cl}_{2}$ the remaining precipitate was filtered and washed with $\mathrm{CH}_{2} \mathrm{Cl}_{2}$. After separation the organic layer was washed with $50 \mathrm{ml}$ of $\mathrm{H}_{2} \mathrm{O}$ (twice), dried on $\mathrm{MgSO}_{4}$, and filtered. After evaporation of the solvent the residue was recrystallised from ethanol. Yields $57-64 \%$.

b $1.6 \mathrm{mmol}$ of the appropriate phosphineoxide was suspended in $10 \mathrm{ml}$ of toluene. Then $1.0 \mathrm{~g}$ (7.04 mmol) of $\left(\mathrm{i}-\mathrm{Bu}_{2}\right) \mathrm{AlH}$ was added dropwise under vigorous stirring; the solid disappeared. The solution was stirred at room temperature for 0.5 $\mathrm{h}$, followed by $0.5 \mathrm{~h}$ at $70^{\circ} \mathrm{C}$ and two hours at reflux temperature. Upon cooling to $0{ }^{\circ} \mathrm{C} 5 \mathrm{ml}$ of ethanol was added dropwise. After addition of $10 \mathrm{ml}$ of $\mathrm{H}_{2} \mathrm{O}$ and $10 \mathrm{ml}$ of $4 \mathrm{n} \mathrm{NaOH}$ in $\mathrm{H}_{2} \mathrm{O}$, the mixture was vigourously shaken for five minutes. After separation, the organic layer was washed twice with $10 \mathrm{ml}$ of $\mathrm{H}_{2} \mathrm{O}$ and dried on $\mathrm{MgSO}_{4}$. After filtration and evaporation of the solvent, the product was recrystallised from ethanol. Yields $62-70 \%$.

\section{Preparation of $[\mathrm{Rh}(\mathrm{COD})(\widehat{\mathrm{PP}})]^{+}\left[\mathrm{ClO}_{4}\right]^{-}(7-9)$}

$0.1831 \mathrm{mmol}$ of $70 \% \mathrm{HClO}_{4}$ was added to a solution of $0.185 \mathrm{mmol}$ of $\mathrm{Rh}(\mathrm{COD}) \mathrm{acac}$ in $50 \mathrm{ml}$ of THF. The colour changed from light yellow to light orange. Subsequently, a solution of 0.1757 mmol of the appropriate diphosphine in $50 \mathrm{ml}$ of THF was added dropwise in about three hours under vigorous stirring.

Stirring was continued for one hour. Upon concentration to $5 \mathrm{ml}$ the product was precipitated by slow addition of diethyl ether and isolated by filtration. The complexes were recrystallised by dissolution in a minimal amount of $\mathrm{CH}_{2} \mathrm{Cl}_{2}$ and addition of an equal volume of ethanol. Stepwise addition of diethyl ether was required to complete crystallisation. Yields 70-90\%. 


\section{Reaction of $[\mathrm{Rh}(\mathrm{COD})(\widetilde{\mathrm{PP}})]^{+}\left[\mathrm{ClO}_{4}\right]^{-}$with $\mathrm{CO}$ $(10-12)$}

$\mathrm{CO}$ gas was bubbled through a solution of about $100 \mathrm{mg}$ of the appropriate $[\mathrm{Rh}(\mathrm{COD})(\mathrm{P} \mathrm{P})]\left[\mathrm{ClO}_{4}\right]$ complex in $3 \mathrm{ml}$ of $\mathrm{CH}_{2} \mathrm{Cl}_{2} / \mathrm{CDCl}_{3}(2: 1)$ for five minutes. The colour changed from dark red-brown to dark orange. The solution thus obtained was used for NMR measurements.

\section{Results and Discussion}

Diphosphinedioxides and Diphosphines (Fig. I)

The diphosphinedioxides $(1-3)$ have been prepared in high yields $(80-90 \%)$ via reaction of two equivalents of the appropriate<smiles>[R20]Oc1ccccc1O[N+](=O)[O-]</smiles>

with di- or triethylene glycol ditosylate.<smiles>[R2][PH](=O)c1ccccc1OCCOCC(C)(C)COc1ccccc1[PH]([R2])=O</smiles><smiles>[R7]c1ccccc1OCC(C)OCC(C)Oc1ccccc1P(O)OC</smiles>

Fig. 1. Diphosphinedioxides: $1 \mathrm{R}, \mathrm{R}^{\prime}=\mathrm{Ph} \mathrm{n}=1 ; 2 \mathrm{R}, \mathrm{R}^{\prime}=$ $\mathrm{Ph} n=2 ; 3 \mathrm{R}=\mathrm{Ph} \mathrm{n}=1 ; \mathrm{R}^{\prime}=$ Me. Diphosphines: $4 \mathrm{R}, \mathrm{R}^{\prime}$ $=\mathrm{Ph} \mathbf{n}=1 ; 5 \mathrm{R}, \mathrm{R}^{\prime}=\mathrm{Ph} \mathbf{n}=2 ; 6 \mathrm{R}=\mathrm{Ph} \mathbf{n}=1 ; \mathrm{R}^{\prime}=\mathrm{Me}$.

For the preparation of the corresponding diphosphines (4-6) by reduction of the diphosphinedioxides, two methods have been employed. Reduction with $\mathrm{Si}_{2} \mathrm{Cl}_{6}$ (method a) or with diisobutylaluminium hydride (method b), followed by hydrolysis, give comparable yields $(60-70 \%)$. In their solid form 4-6 are stable; in solution only 6 is sensitive to air. Compounds $1-6$ are spectroscopically characterised. The NMR data are given in Tables I and II. In the case of 3 and 6 racemic mixtures are obtained. In the ${ }^{31}$ P-NMR of 6 two signals are found, attributable to the two diastereomers.

\section{$\left.[\mathrm{Rh} / \mathrm{COD})(\widehat{\mathrm{PP}})] / \mathrm{ClO}_{4}\right]$ Complexes}

Reaction between $\mathrm{Rh}(\mathrm{COD}) \mathrm{acac}, \mathrm{HClO}_{4}$ and the appropriate diphosphine gives in moderate yields the $c i s-[\mathrm{Rh}(\mathrm{COD})(\mathrm{PP})]\left[\mathrm{ClO}_{4}\right]$ complexes.
In general a mixture of various species is obtained, as described previously for the $\mathrm{Ph}_{2} \mathrm{PCH}_{2} \mathrm{CH}_{2}\left(\mathrm{OCH}_{2}\right.$ $\left.\mathrm{CH}_{2}\right)_{n} \mathrm{PPh}_{2}$ analogues $(\mathrm{n}=1,2,3)$ [3]. Apparently, the resulting $[\mathrm{Rh}(\mathrm{COD})(\mathrm{P} \mathrm{P})]\left[\mathrm{ClO}_{4}\right]$ complexes are not very stable and tend to lose COD. This is supported by the observation that on recording the NMR spectrum, gradually more signals arise, due to slow decomposition in $\mathrm{CDCl}_{3}$.

The ${ }^{31}$ P-NMR parameters of the complexes are shown in Table III. We have only tabulated the main signals. For 7-9 in each of the three cases a doublet is observed, which we assign to arise from a monomeric species $(\mathbf{7} \mathbf{a}-\mathbf{9 a})$, the structure of which is shown in Fig. 2.

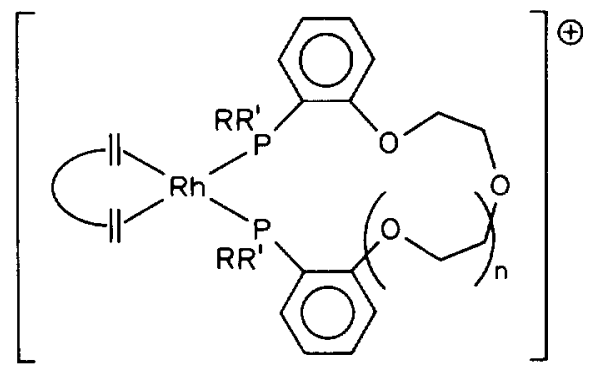

Fig. 2. Proposed structure of $[\mathrm{Rh}(\mathrm{COD})(\overparen{\mathrm{PP}})]\left[\mathrm{ClO}_{4}\right]$ : 7a $\mathrm{R}, \mathrm{R}^{\prime}=\mathrm{Ph} \mathbf{n}=1 ;\left(8 \mathrm{a} \mathbf{R}, \mathbf{R}^{\prime}=\mathbf{P h} \mathbf{n}=2\right) ; 9 \mathrm{a} \mathbf{R}=\mathbf{P h} \mathbf{R}^{\prime}=\mathrm{Me}$ $\mathrm{n}=1$.

It is noticeable that the ${ }^{1} J(\mathrm{Rh}-\mathrm{P})$ couplings for 7a-9a differ considerably, viz. $128.78 \mathrm{~Hz}, 170.90$ $\mathrm{Hz}$ and $144.04 \mathrm{~Hz}$, respectively. This difference may point to a difference between the three ligands with regard to interaction of the ether oxygens with the metal centre. For the analogous [Rh(COD)$\left.\left(\mathrm{Ph}_{2} \mathrm{PCH}_{2} \mathrm{CH}_{2}\left(\mathrm{OCH}_{2} \mathrm{CH}_{2}\right)_{\mathrm{n}} \mathrm{PPh}_{2}\right)\right]\left[\mathrm{ClO}_{4}\right] \quad(\mathrm{n}=1-3)$ complexes we have found a ${ }^{1} J(\mathrm{Rh}-\mathrm{P})$ coupling of about $144 \mathrm{~Hz}$ [3].

In the ${ }^{31}$ P-NMR spectrum of 7 two quartets are observed as well, arising from a species $b$, with two unequivalent phosphino groups in cis-position to each other as can be seen from the ${ }^{2} J(\mathrm{P}-\mathrm{P})$ value of $22.58 \mathrm{~Hz}$. The two ${ }^{1} J(\mathrm{Rh}-\mathrm{P}$ ) values (of 117.80 and of $120.24 \mathrm{~Hz}$ ) indicate that the Rh-centre is not four-coordinate. The high downfield shifts of 43.00 and $53.53 \mathrm{ppm}$, respectively, point out that both $\mathrm{P}$ nuclei and therefore also the metal centre are less electron-rich. We think that $7 \mathbf{b}$ has lost the COD ligand, because chemical analysis of an unpurified sample evidently shows lower $\mathrm{C}$ and $\mathrm{H}$ percentages. Moreover, in the ${ }^{1} \mathrm{H}-\mathrm{NMR}$ spectrum the olefine signals are entirely absent. The absence of COD is further confirmed by the fact that $7 \mathbf{b}$ does not react with $\mathrm{CO}$ at all. The proposed structure with all three ether oxygens coordinated is shown in Fig. 3. 
TABLE 1. ${ }^{1} \mathrm{H}$ - and ${ }^{31}$ P-NMR Data of the Diphosphinedioxides and Diphosphines. Spectra measured in $\mathrm{CDCl}_{3}$.

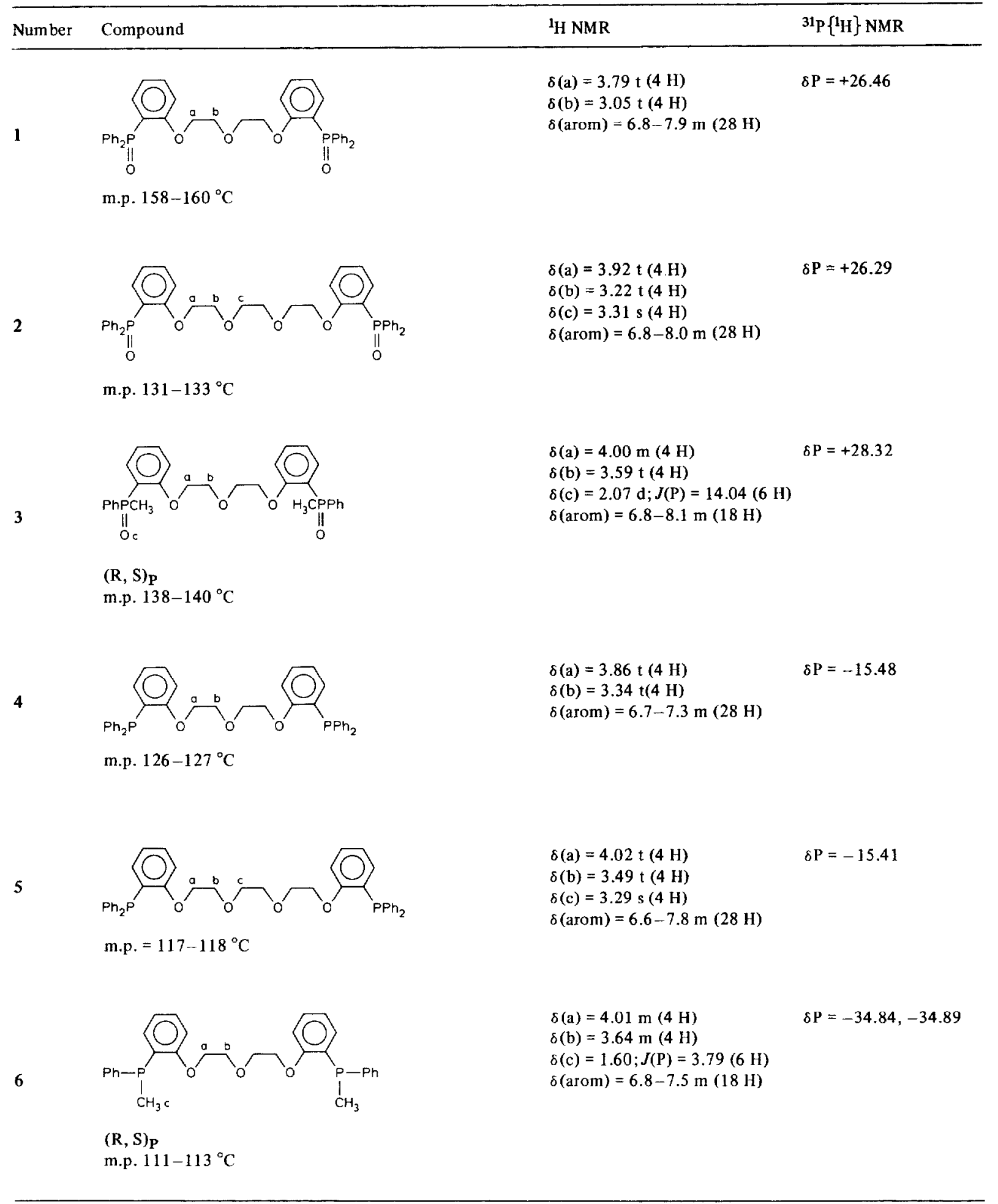

Reaction of $\left[\mathrm{Rh}(\mathrm{COD})(\stackrel{\mathrm{PP}}{\mathrm{P}}) /\left[\mathrm{ClO}_{4}\right]\right.$ with $\mathrm{CO}$

In order to examine the coordination behaviour of the diphosphines upon displacement of the cis- coordinated COD ligand, we have reacted complexes $7 \mathrm{a}-9 \mathrm{a}$ with $\mathrm{CO}$, yielding 10-12.

As seen from Table III, ${ }^{1} J(\mathrm{Rh}-\mathrm{P})$ for the CO- 
TABLE II. ${ }^{13} \mathrm{C}$-NMR Data of the Diphosphines. Spectra measured in $\mathrm{CDCl}_{3}$.

\begin{tabular}{|c|c|c|c|}
\hline Number & Compound & $\delta(\mathrm{C})$ & $J(\mathrm{P})$ \\
\hline \multirow{12}{*}{4} & & $\delta\left(C_{1}\right)=136.76$ & $J(\mathrm{P})=11.03$ \\
\hline & & $\delta\left(C_{2}\right)=133.87$ & $J(\mathrm{P})=20.22$ \\
\hline & & $\delta\left(C_{3}\right)=128.21$ & $J(\Gamma)=7.35$ \\
\hline & & $\delta\left(C_{4}\right)=128.40$ & $J(\mathrm{P})=0$ \\
\hline & & $\delta\left(C_{1}^{\prime}\right)=126.11$ & $J(\mathrm{P})=12.90$ \\
\hline & & $\delta\left(C_{2^{\prime}}\right)=160.14$ & $J(\mathrm{P})=14.30$ \\
\hline & & $\delta\left(C_{3^{\prime}}\right)=111.21$ & $J(\mathrm{P})=1.49$ \\
\hline & & $\delta\left(C_{4}^{\prime}\right)=130.03$ & $J(\mathrm{P})=0$ \\
\hline & & $\delta\left(C_{5^{\prime}}\right)=121.01$ & $J(\mathrm{P})=0$ \\
\hline & & $\delta\left(C_{6^{\prime}}\right)=133.30$ & $J(\mathrm{P})=0$ \\
\hline & & $\delta\left(C_{7}\right)=69.28$ & \\
\hline & & $\delta\left(\mathrm{C}_{8}\right)=68.01$ & \\
\hline \multirow{13}{*}{5} & & $\delta\left(C_{1}\right)=136.73$ & $J(\mathrm{P})=10.66$ \\
\hline & & $\delta\left(C_{2}\right)=133.87$ & $J(\mathrm{P})=20.22$ \\
\hline & & $\delta\left(C_{3}\right)=128.24$ & $J(\mathrm{P})=7.35$ \\
\hline & & $\delta\left(\mathrm{C}_{4}\right)=128.47$ & $J(\mathrm{P})=0$ \\
\hline & & $\delta\left(C_{1},\right)=126.12$ & $J(\mathrm{P})=12.87$ \\
\hline & & $\delta\left(C_{2^{\prime}}\right)=160.14$ & $J(\mathrm{P})=14.71$ \\
\hline & & $\delta\left(\mathrm{C}_{3^{\prime}}\right)=111.21$ & $J(\mathrm{P})=1.47$ \\
\hline & & $\delta\left(\mathrm{C}_{4^{\prime}}\right)=130.08$ & $J(\mathrm{P})=0$ \\
\hline & & $\delta\left(C_{5^{\prime}}\right)=121.14$ & $J(\mathrm{P})=0$ \\
\hline & & $\delta\left(C_{6^{\prime}}\right)=133.33$ & $J(\mathrm{P})=0$ \\
\hline & & $\delta\left(C_{7}\right)=69.12$ & \\
\hline & & $\delta\left(C_{8}\right)=68.19$ & \\
\hline & & $\delta\left(C_{9}\right)=70.68$ & \\
\hline \multirow{14}{*}{6} & & $\delta\left(C_{1}\right)=139.61$ & $J(\mathrm{P})=11.40$ \\
\hline & & $\delta\left(C_{2}\right)=132.39$ & $J(\mathrm{P})=19.49$ \\
\hline & & $\delta\left(C_{3}\right)=128.10$ & $J(\mathrm{P})=6.99$ \\
\hline & & $\delta\left(C_{4}\right)=128.18$ & $J(\mathrm{P})=0$ \\
\hline & 56 & $\delta\left(C_{1^{\prime}}\right)=129.27$ & $J(\mathrm{P})=18.75$ \\
\hline & & 128.56 & 13.60 \\
\hline & & $\delta\left(\mathrm{C}_{2^{\prime}}\right)=160.05$ & $J(\mathrm{P})=12.13$ \\
\hline & & $\delta\left(\mathrm{C}_{3^{\prime}}\right)=111.21$ & $J(\mathrm{P})=1.10$ \\
\hline & & $\delta\left(C_{4^{\prime}}\right)=129.69$ & $J(\mathbf{P})=0$ \\
\hline & & $\delta\left(C_{s^{\prime}}\right)=120.94$ & $J(\mathrm{P})=2.57$ \\
\hline & & $\delta\left(C_{6^{\prime}}\right)=131.71$ & $J(\mathrm{P})=6.25$ \\
\hline & & $\delta\left(C_{7}\right)=69.48$ & \\
\hline & & $\delta\left(C_{8}\right)=67.72$ & \\
\hline & & $\delta\left(C_{9}\right)=11.02$ & $J(\mathrm{P})=12.87$ \\
\hline
\end{tabular}

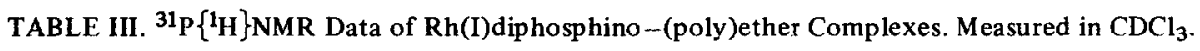

\begin{tabular}{|c|c|c|c|c|}
\hline & & $\delta P$ & ${ }^{1} J(\mathrm{Rh}-\mathrm{P})$ & ${ }^{2} J(\mathrm{P}-\mathrm{P}) c i s$ \\
\hline $7 \mathbf{a}$ & {$[\mathrm{Rh}(\mathrm{COD})(4)]\left[\mathrm{ClO}_{4}\right]$} & 25.95 & 128.78 & \\
\hline \multirow[t]{2}{*}{$7 \mathrm{~b}$} & see text & $43.00(\mathrm{P} 1)$ & 117.80 & 22.58 \\
\hline & & $53.53(\mathrm{P} 2)$ & 120.24 & 22.58 \\
\hline 10 & {$[\mathrm{Rh}(\mathrm{CO})(4)]\left[\mathrm{ClO}_{4}\right]^{\mathrm{a}}$} & 19.25 & 105.59 & \\
\hline $\mathbf{8 a}$ & {$[\mathrm{Rh}(\mathrm{COD})(5)]\left[\mathrm{ClO}_{4}\right]$} & 31.62 & 170.90 & \\
\hline 11 & {$[\mathrm{Rh}(\mathrm{CO})(5)]\left[\mathrm{ClO}_{4}\right]^{\mathrm{b}}$} & 28.16 & 152.90 & \\
\hline $9 \mathbf{a}$ & {$[\mathrm{Rh}(\mathrm{COD})(6)]\left[\mathrm{ClO}_{4}\right]$} & 1.47 & 144.04 & \\
\hline 12 & {$[\mathrm{Rh}(\mathrm{CO})(6)]\left[\mathrm{ClO}_{4}\right]^{\mathrm{c}}$} & 6.58 & 127.23 & \\
\hline
\end{tabular}

$a_{\nu(C O)}=1977$ vs. $\quad b_{\nu(C O)}=1973 \mathrm{sh}, 2005 \mathrm{~m} . \quad c_{\nu(C O)}=2025 \mathrm{~s}, 1968 \mathrm{~m}$. 


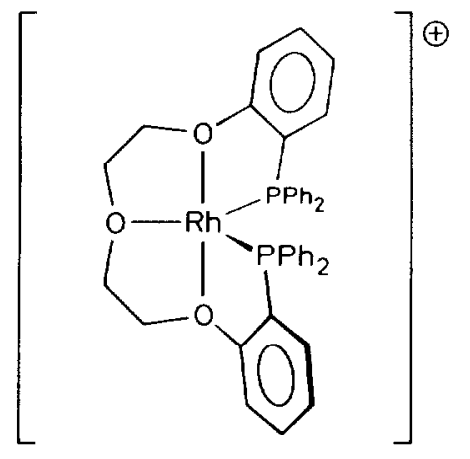

Fig. 3. Proposed structure of $7 \mathbf{b}$.

complex is $17-23 \mathrm{~Hz}$ lower than ${ }^{1} J(\mathrm{Rh}-\mathrm{P})$ for the corresponding $\mathrm{COD}$ complex. For the anlalugous $\left[\mathrm{Rh}(\mathrm{CO})\left(\mathrm{Ph}_{2} \mathrm{PCH}_{2} \mathrm{CH}_{2} \mathrm{OCH}_{2} \mathrm{CH}_{2} \mathrm{PPh}_{2}\right)\right]\left[\mathrm{ClO}_{4}\right]$ we have found a decrease of $1 J(\mathrm{Rh}-\mathrm{P})$ of $15 \mathrm{~Hz}$. in comparison with the value of ${ }^{1} J(\mathrm{Rh}-\mathrm{P})$ for [Rh(COD) $\left.\left(\mathrm{Ph}_{2} \mathrm{PCH}_{2} \mathrm{CH}_{2} \mathrm{OCH}_{2} \mathrm{CH}_{2} \mathrm{PPh}_{2}\right)\right]\left[\mathrm{ClO}_{4}\right]$ [5]. Determination of the X-ray structure of the former compound by Alcock et al. has revealed transcoordination of $\mathrm{CO}$ and the ether oxygen [6]. For this complex we have observed $\nu(\mathrm{CO})$ at 1974 $\mathrm{cm}^{-1}$. Also because we find $v(\mathrm{CO})$ for $10-12$ in the same range, we propose a structure similar to that determined by Alcock, which is shown in Fig. 4.

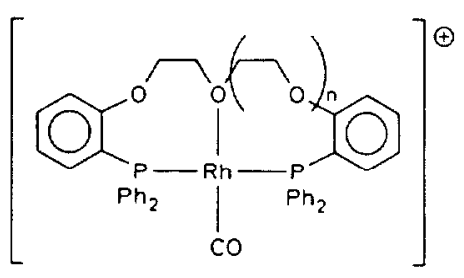

Fig. 4. Proposed structure of $10-12: 10 \mathrm{R}, \mathrm{R}^{\prime}=\mathrm{Ph} \mathrm{n}=1$; $11 \mathrm{R}, \mathrm{R}^{\prime}=\mathrm{Ph} \mathrm{n}=2 ; 12 \mathrm{R}=\mathrm{Ph} \mathrm{R}^{\prime}=\mathrm{Men}=1$.

\section{Acknowledgements}

The authors wish to thank Dr. J. G. Noltes for stimulating discussions and Dr. J. W. Marsman for recording the NMR spectra.

\section{References}

1 A. H. Alberts, K. Timmer, J. G. Noltes and A. L. Spek, J. Am. Chem. Soc., 101, 3375 (1979).

2 T. S. Lobana and S. S. Sandhu, Coord. Chem. Revs., 47, 283 (1982) and references therein.

3 D. H. M. W. Thewissen, K. Timmer, J. G. Noltes, J. W. Marsman and R. M. Laine, Inorg. Chim. Acta, 97, 143 (1985).

4 D. Sinnu and H. B. Kagan, J. Organomet. Chem., 114, 325 (1976).

5 D. H. W. M. Thewissen and K. Timmer, unpublished results.

6 N. W. Alcock, J. M. Brown and J. C. Jeffery, J. Chem. Soc. Dalton Trans., 583 (1976). 